\title{
THE
}

\section{Life at Stable Low Oxygen Levels: Adaptations of Animals to Oceanic Oxygen Minimum Layers}

James J. Childress

Brad A. Seibel

University of Rhode Island, seibel@uri.edu

Follow this and additional works at: https://digitalcommons.uri.edu/bio_facpubs

Terms of Use

All rights reserved under copyright.

\section{Citation/Publisher Attribution}

Childress, J.J.; Seibel, B.A.; 1998. Life at stable low oxygen levels: adaptations of animals to oceanic oxygen minimum layers. The Journal of Experimental Biology 201, 1223-1232.

Available at: http://jeb.biologists.org/content/201/8/1223

This Article is brought to you for free and open access by the Biological Sciences at DigitalCommons@URI. It has been accepted for inclusion in Biological Sciences Faculty Publications by an authorized administrator of DigitalCommons@URI. For more information, please contact digitalcommons-group@uri.edu. 


\title{
LIFE AT STABLE LOW OXYGEN LEVELS: ADAPTATIONS OF ANIMALS TO OCEANIC OXYGEN MINIMUM LAYERS
}

\author{
JAMES J. CHILDRESS* AND BRAD A. SEIBEL \\ Department of Ecology, Evolution and Marine Biology and Marine Science Institute, University of California, \\ Santa Barbara, CA 93106, USA \\ *e-mail: childres@lifesci.uscb.edu
}

Accepted 6 November 1997; published on WWW 24 March 1998

\begin{abstract}
Summary
Zones of minimum oxygen level are found at intermediate depths in most of the world's oceans and, although the oxygen partial pressure in some of these 'oxygen minimum layers' is only a fraction of a kilopascal, populations of pelagic metazoans exist there. These oxygen minimum layers are areas of the water column and the associated benthos with stable conditions of continuously low oxygen level and low temperature at intermediate depths (400-1000 $\mathrm{m}$ depth) over vast areas. Off California, where $P_{\mathrm{O}_{2}}$ at the oxygen minimum is $0.8 \mathrm{kPa}$, there are abundant populations of animals both in the water column and on the bottom. Farther to the south in the eastern tropical Pacific, oxygen partial pressures of less than approximately $0.4 \mathrm{kPa}$ result in very low biomasses and diversity of animals at minimum layer depths.

At the minimum oxygen levels found off California, most animals which inhabit the minimum zones appear to support their routine metabolic demands via aerobic metabolism. They do this by being very effective at removing oxygen from water. Among the adaptations of pelagic crustaceans to these conditions are: (1) enhanced ventilatory abilities, (2) enhanced percentage removal of $\mathrm{O}_{2}$

(5) hemocyanin respiratory proteins with a very high affinity for $\mathrm{O}_{2}$, high cooperativity and large Bohr effects. The lower $\mathrm{O}_{2}$ consumption rates of many deeper-living species are also functionally adaptive in that they facilitate aerobic survival at low $P_{\mathrm{O}_{2}}$. However, they are not adaptations to the minimum layer, since similarly low rates are found in the same and comparable species living at the same depths in regions without well-developed minima, and these animals are unable to survive at the low $P_{\mathrm{O}_{2}}$ values of the minima. While anaerobic metabolism may be important for metabolic rates above the routine level for most animals in the minimum layer, there is little evidence for the use of sustained anaerobiosis in the species studied. In summary, given the stable presence of very low $\mathrm{O}_{2}$ levels in the minima, the primary adaptations of animals living within them are those that support aerobic metabolism by giving the animals remarkable abilities to extract $\mathrm{O}_{2}$ from water. These abilities are notably better than those of animals adapted to unstable hypoxic environments, such as intertidal mudflats, while the latter animals rely to a much greater extent on anaerobiosis and perhaps on metabolic suppression to survive periods of anoxia.
\end{abstract} from the ventilatory stream, (3) large gill surface areas, (4) short diffusion distances from the water to the blood, and
Key words: oxygen minimum layer, metabolic rate, adaptation.

\section{Introduction}

Zones of minimum oxygen level are found at intermediate depths in most of the world's oceans and, although the oxygen partial pressures of these 'oxygen minimum layers' in some regions are only a fraction of a kilopascal, populations of pelagic metazoans exist there (Schmidt, 1925; Sewell and Fage, 1948; Banse, 1964). These oxygen minimum layers (OMLs) are pelagic habitats with stable conditions of continuously low oxygen level and low temperature at intermediate depths (400-1000 m depth) over vast areas. Where the OMLs intersect continental margins, stable lowoxygen conditions are also found in the benthic habitat. The oceanic oxygen minima differ from other hypoxic aquatic habitats in that very low oxygen levels are stable over long periods and large areas, while other aquatic hypoxic habitats are typically short-lived, transient stages in the progression to anoxia where the region of hypoxia is quite small. One result of this is that OML inhabitants have dramatic adaptations for aerobic metabolism which often exceed those found in animals from other hypoxic habitats.

The oxygen minimum layers as oceanographic phenomena

The best-developed OMLs are found in the eastern tropical Pacific Ocean, the Northern Indian Ocean and the Eastern Atlantic off northwest Africa (Wyrtki, 1962; Kamykowski and Zentara, 1990; Olson et al. 1993). In these regions, the minimum oxygen level is typically less than $0.1 \mathrm{ml}^{-1}$ at depths 


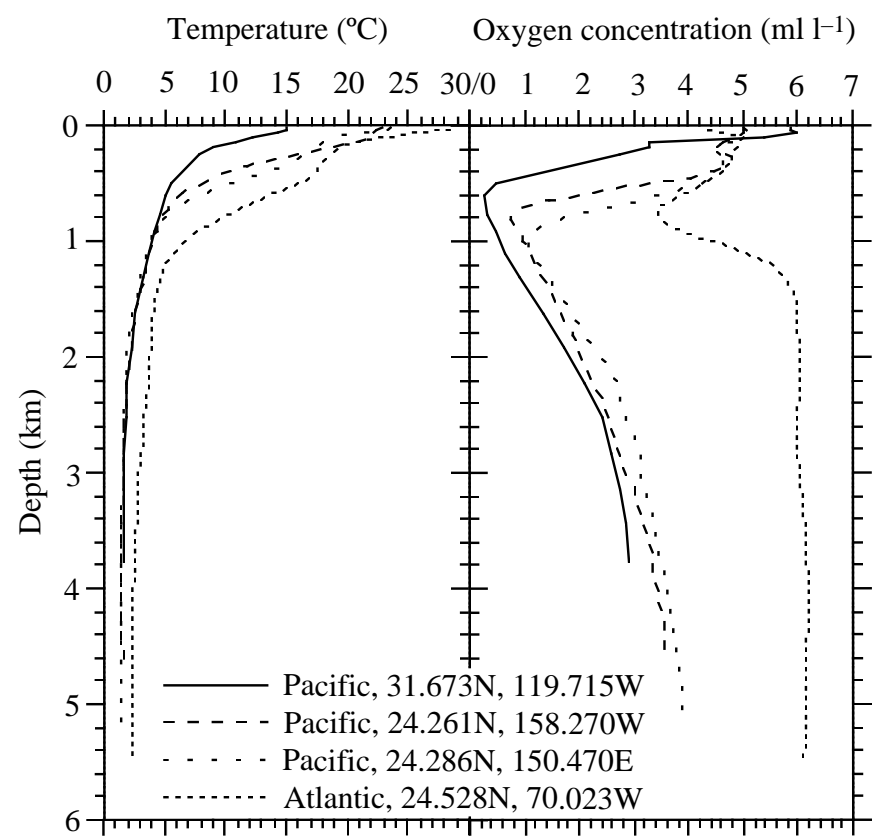

Fig. 1. Oxygen levels and temperature conditions as a function of depth at oceanic stations in the Pacific and Atlantic Oceans. Pacific temperature and $\mathrm{O}_{2}$ data are taken from a March-June 1985 section along $24^{\circ} \mathrm{N}$ from the Trans-Pacific Sections expedition of the RV Thompson. Atlantic temperature and $\mathrm{O}_{2}$ data are taken from an August-September 1981 cruise of RV Atlantis II. Both groups of data are taken from the data files accompanying the OceanAtlas program using OceanAtlas for access.

of $600-800 \mathrm{~m}$ and often over depths of $100-900 \mathrm{~m}$. As one moves horizontally out from these 'core' regions, the minimum is reduced in thickness and the minimum oxygen level is higher (Fig. 1). These oxygen minima develop because the balance of consumption of oxygen relative to replenishment is greater than at shallower and greater depths. At shallower depths, the consumption is higher but the oxygen supply is even higher, while at greater depths the oxygen supply is lower but, owing to the greatly decreased biomass, the consumption is much lower. In areas where the OML is especially well developed, the 'source' waters are typically relatively low in oxygen and/or their circulation through the regions is slow (Wyrtki, 1962, 1967; Olson et al. 1993), resulting in low replenishment of oxygen. High local primary production may also be a factor contributing to oxygen depletion.

As already noted, the oceanic oxygen minima persist for long periods, making this habitat different from other hypoxic marine habitats in that hypoxia is not a short-lived, transient condition between oxic and anoxic conditions. Furthermore, because of the great extent of the habitat, the quantity of oxygen is not a limiting factor as it may be in many of the limited-volume, transiently hypoxic marine habitats. To put the stability of deep-sea oxygen conditions in perspective, we will briefly consider our present knowledge about the past history of oxygenation in the deep sea. Present estimates from paleaoceanography are that the deep sea has been oxic for the last 90 million years (Herbert and Sarmiento, 1991; Kaiho, 1991; Tyson and Pearson, 1991), although prior to that time there were periods of anoxia. A more recent event, 57.33 million years ago, apparently involved pronounced warming and reduction of oxygen concentrations in the deep sea but is unlikely to have produced anoxia, although it caused the extinction of many deep-sea benthic species (Kennett and Stott, 1991). More recently, studies of high-resolution palaeoclimatic and palaeoceanographic records from the Santa Barbara basin (which is at oxygen minimum depths) show relatively short-term oscillations between low-oxygen conditions (indicated by laminated sediments and correlated with warmer climate) and higher-oxygen conditions (indicated by the absence of laminations due to bioturbation and correlated with a cooler climate) during the last 20000 years (Kennett and Ingram, 1995). These variations appear to be synchronous with ocean-climate variations at more distant points, suggesting widespread variations in the oxygen content of the oxygen minimum layers, with conditions being stable for only thousands of years at a time. In this context, we envision a world ocean in which the oxygen minima are always present, but the extent of the regions of lowest oxygen level varies considerably, with major oscillations having periods measured in thousands of years. In terms of the physiological adaptations of the midwater biota, this means that animals are faced either with having their vertical or horizontal ranges modified as ambient oxygen conditions change at intermediate depths or with being able to acclimate to the changed conditions. These possibilities warrant further study to discover which strategy is used by these organisms.

\section{The impact of oceanic oxygen minimum layers on animal distributions}

Perhaps the most striking observation is that, over a very wide range of oxygen contents and partial pressures (down to approximately $0.20 \mathrm{ml}^{-1}$ or $0.63 \mathrm{kPa}$ ), there is apparently no effect of the low oxygen levels on the biomasses of midwater organisms and relatively little effect even on the distributions of major taxa and of many particular species (Banse, 1964). This is especially noteworthy because these oxygen contents are far below those normally considered hypoxic in shallower habitats $(4-13 \mathrm{kPa})$ and are beyond the aerobic abilities of most shallower-living species. However, there is evidence that, even at these oxygen partial pressures, which do not reduce the animal biomass, particular species may be excluded while others may be limited to low-oxygen conditions (Pickford, 1946; Gibbs and Hurwitz, 1967; Roper, 1969; Brinton, 1979).

At oxygen concentrations below approximately $0.15 \mathrm{ml}^{-1}$, there are pronounced effects on both species distributions and biomass. Typically, the zooplankton biomass is greatly reduced within these OMLs, and there is a secondary maximum of biomass at the lower edge of the OML where oxygen content is rising (Jesperson, 1935; Sewell and Fage, 1948; Vinogradov and Voronina, 1962; Childress, 1968; 


\section{Life at stable low oxygen levels 1225}

Brinton, 1979; Judkins, 1980; Wishner et al. 1990; BöttgerSchnack, 1996; Saltzman and Wishner, 1997a,b). Those few species that do live in these very low oxygen concentrations are typically diurnal vertical migrators which enter shallower, more oxygenated waters at night (Vinogradov and Voronina, 1962; Longhurst, 1967; Childress, 1968; Brinton, 1979; Sameoto et al. 1987; Kinzer et al. 1993; Saltzman and Wishner, 1997a,b).

\section{Adaptations of animals to the oxygen minimum layers}

Within the vast oceanic realm, the problem of hypoxia is entirely one of a reduced gradient to drive diffusion of oxygen from the exterior of the animals eventually to their mitochondria. The quantity of oxygen in their environment is not limiting, just its availability. Thus, given the much higher energy yield of aerobic metabolism, one would expect that there would be strong selection for mechanisms to take up oxygen effectively from very low ambient partial pressures. However, at some point, one would expect that the available gradient would be too small to support aerobic metabolism fully, even with highly developed uptake mechanisms, and this could result either in a shift to anaerobic metabolism or to a reduction in metabolic rates. Thus, the three modes of adaptation to the oxygen minima which have been proposed are as follows. (1) The development of mechanisms for the highly effective removal of oxygen from water, allowing an animal to regulate its rate of oxygen consumption down to low partial pressures. (2) The reduction of metabolic rates so that the organism can live at lower oxygen partial pressures with a given set of uptake mechanisms. (3) The use of anaerobic metabolism to make up the difference between aerobic capacity and total metabolic demand. This could be on a sustained basis, during periods of increased demand due to higher activity or during transient periods spent in the oxygen minimum layer by diurnal vertical migrators. As we shall see below, there is evidence for all of these mechanisms depending upon the severity of the oxygen minimum, the complexity of the animals considered and the oceanic habitat involved.

The severity of the oxygen minimum is expected to be an especially critical factor below approximately $0.15 \mathrm{mll}^{-1}$ $(0.48 \mathrm{kPa})$ since zooplankton biomasses are significantly reduced below this level. This suggests that there is a limit to the adaptations used throughout the less intensely developed minima at approximately $0.15 \mathrm{mll}^{-1}$, with other strategies being required at lower oxygen levels. One of the goals of this paper is to consider the nature of this apparent limitation.

The structural complexity of the many taxa of animals found in the pelagic environment is another significant variable affecting the adaptations expected. Some groups, such as fishes, crustaceans, molluscs and polychaetes, have specialized respiratory surfaces, circulatory systems and respiratory systems which offer many possibilities for adaptive modifications. However, many other groups, such as the cnidarians, ctenophores, radiolarians and nemerteans, lack such organs and tissues yet are found in the oxygen minima.
They may well use different mechanisms to survive from those used by the more structurally complex taxa.

For pelagic species, higher oxygen partial pressures could potentially be accessed by swimming vertically for a few hundred meters; however, many of the species found in the minimum layer appear to spend extended periods there. In contrast, benthic species within an OML would typically need to go many kilometers along the bottom to change their depths sufficiently to find higher oxygen levels. This difference between the benthic and pelagic habitats may affect the kinds of adaptations found in these two habitats. As a result, we will primarily consider the pelagic species, for which there is a rich literature, and specifically discuss the much more limited literature on benthic species when appropriate.

The adaptive significance of the properties of species living in an oxygen minimum can be difficult to dissect because almost all the important variables such as oxygen level, temperature, downwelling light, pressure and zooplankton biomass covary with depth in the top $1000 \mathrm{~m}$ or so of the ocean. This means that, within a given geographic area, these variables are almost hopelessly confounded and it is difficult, if not impossible, to demonstrate an adaptive response to one of them when working within a single region (Childress, 1995). What is necessary for a definitive comparison is a horizontal comparison between species, or of the same species, living at the same depths but in regions with differing hydrographic properties. In the case of adaptation to the oxygen minimum, this means comparing animals from regions with different oxygen contents in the minimum layer. Comparisons among species living above the oxygen minimum and in it in a single region are exceedingly difficult to interpret because of the confounding of so many variables with depth (Childress, 1995). In some cases, survival at depth conditions, modeling or comparisons with deeper-living species can be useful approaches to testing whether a given parameter is an adaptation to low oxygen level.

Another possible problem in applying a comparative approach to the question of adaptation to the minimum layers is that phylogeny may have played a significant role in the evolution of the properties of individual species, and thus some workers contend that each species cannot be considered to provide an independent data point (Harvey and Pagel, 1991). We do not believe that this is a problem within the large data sets on pelagic species that we will be primarily considering, since these data sets show a great deal of convergence of properties across phyla, genera and families for species living within the minima (Childress, 1995). However, there is also much evidence of divergence of properties within genera and families as a function of whether they live within minima or not.

\section{Aerobic adaptation to the oxygen minimum layer}

It is clear that an enhanced ability to regulate oxygen uptake is fundamental to the survival of animals in the oxygen minimum layers. OML-dwelling midwater crustaceans, fishes and cephalopods from the oceans off California generally have 


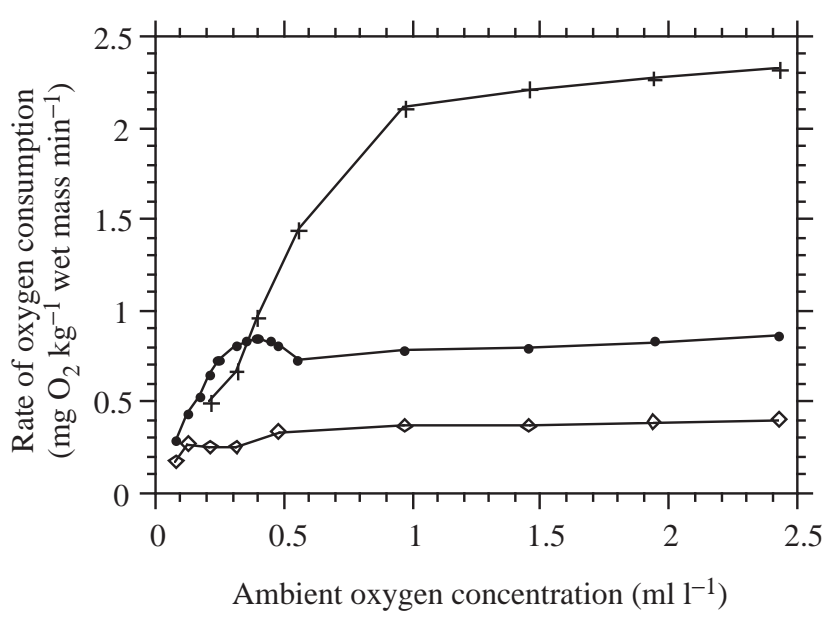

Fig. 2. Rates of oxygen consumption of Gnathophausia ingens from the seas off California measured at $5.5^{\circ} \mathrm{C}$ (Childress, 1968). Crosses represent a single animal driven to maximal activity. Filled circles represent the means of 23 runs with eight individuals showing routine levels of swimming activity. Diamonds represent a single nonswimming animal.

the ability to regulate their routine oxygen consumption rates down to approximately the lowest oxygen level that they encounter in the ocean (Childress, 1968, 1969, 1971a,b, 1995; Meek and Childress, 1973; Torres et al. 1979; Seibel et al. 1997) (Fig. 2). In some cases, the critical partial pressures $\left(P_{\mathrm{c}}\right)$ where regulation of $\mathrm{O}_{2}$ uptake failed were as low as $0.4 \mathrm{kPa}$. These enhanced regulatory abilities are clearly an adaptation to the minimum layer since (1) similar species or the same species from the same depths but from regions with higher oxygen levels have higher $P_{\mathrm{c}}$ values and cannot survive at lower $P_{\mathrm{O}_{2}}$ values for any time (Donnelly and Torres, 1988; Cowles et al. 1991; Torres et al. 1994a,b; Seibel et al. 1997), (2) species that live below the minimum layer have higher $P_{\mathrm{c}}$ values (Childress, 1975), and (3) OML species generally have very limited anaerobic abilities. In one case, a benthic fish living within the minimum off southern California has also been found to have a low $P_{\mathrm{c}}$ (Yang et al. 1992), indicating aerobic adaptations in benthic species as well.

Fig. 3 summarizes the available data on the regulation of oxygen consumption by OML-depth midwater crustaceans from the seas off southern California, Hawaii, the Gulf of Mexico and the Antarctic. This graph shows that the pelagic crustaceans have $P_{\mathrm{c}}$ values which generally enable them to maintain their aerobic metabolic rates even at the lowest $\mathrm{O}_{2}$ concentrations in their environments. However, those species from regions with higher oxygen concentrations have much higher $P_{\mathrm{c}}$ values. The apparent flattening of the curve above a $P_{\mathrm{c}}$ of $4 \mathrm{kPa}$ suggests that $P_{\mathrm{c}}$ values below $4 \mathrm{kPa}$ are specific adaptations to reduced environmental oxygen levels in the minimum layer, while $P_{\mathrm{c}}$ values of approximately $4 \mathrm{kPa}$ appear to be typical of midwater animals living at high environmental oxygen levels. Differences in the $P_{\mathrm{c}}$ in individuals from the same species caught in regions of differing minimum $\mathrm{O}_{2}$ have also been documented, suggesting either an ability to acclimate

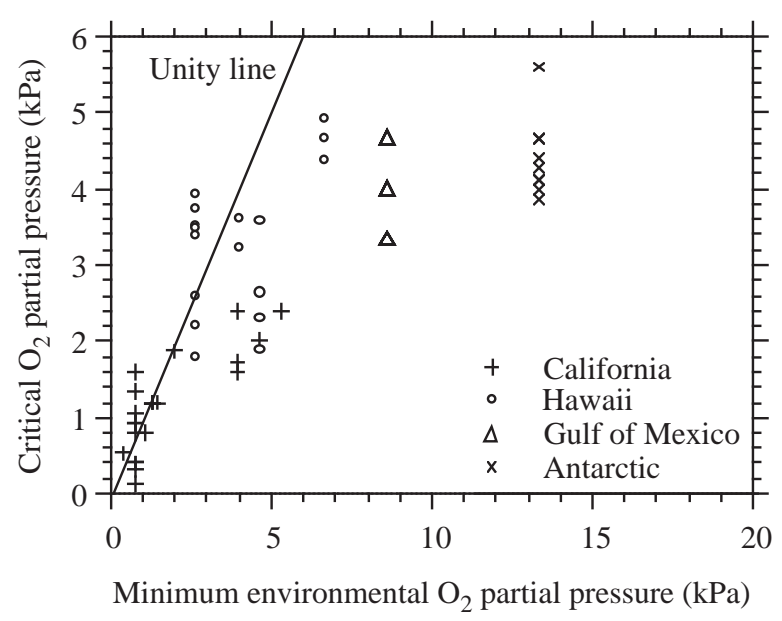

Fig. 3. The mean critical $\mathrm{O}_{2}$ partial pressures of a wide variety of pelagic crustaceans living at oxygen minimum layer depths in different oceanic habitats plotted as a function of the lowest $P_{\mathrm{O}_{2}}$ to which they are normally exposed (Childress, 1975; Donnelly and Torres, 1988; Cowles et al. 1991; Torres et al. 1994). Since the lowest $P_{\mathrm{O}_{2}}$ in a given region is common to many species, there is a great deal of overlap of points so that, while 43 points are apparent, 62 are actually plotted.

their regulatory abilities or regional genetic differences in widespread OML-depth species (Sanders and Childress, 1990a,b; Cowles et al. 1991).

These enhanced regulatory abilities appear to be the result of a very high degree of development of the systems involved in uptake and transport of oxygen (Childress, 1995). In the most detailed studies of an animal from the oxygen minimum layer undertaken to date (Childress, 1968, 1971a; Belman and Childress, 1976; Sanders and Childress, 1990a,b), the mysid crustacean Gnathophausia ingens (which has a routine $P_{\mathrm{c}}$ of $0.8 \mathrm{kPa}$ ) has been shown to have the following properties which facilitate oxygen uptake at low partial pressures: (1) high ventilatory abilities (up to $81 \mathrm{~kg}^{-1} \mathrm{~min}^{-1}$ ); (2) high effectiveness of removal of $\mathrm{O}_{2}$ from ventilatory stream (up to $90 \%$ removal from inhaled water); (3) high circulatory capacity (up to $225 \mathrm{ml} \mathrm{kg}^{-1} \mathrm{~min}^{-1}$ ); (4) high gill surface area (9-14 $\mathrm{cm}^{2} \mathrm{~g}^{-1}$ wet body mass); (5) thin blood-to-water diffusion distance across the gills $(1.5-2.5 \mu \mathrm{m})$; and (6) hemocyanin with a high affinity for $\mathrm{O}_{2}\left(P_{50}=0.19 \mathrm{kPa}\right)$, high cooperativity $\left(N_{50}=3.5\right)$, large Bohr effect $\left(-0.80 \Delta \log P_{50} \Delta \mathrm{pH}^{-1}\right)$ and low concentration $\left(24 \mathrm{mg} \mathrm{ml}^{-1}\right.$ or $\left.0.3 \mathrm{mmol} \mathrm{O}_{2} \mathrm{l}^{-1}\right)$.

The first five of these properties are comparable to those of active fishes (Childress, 1971a,b; Belman and Childress, 1976). The high gill surface area and thin blood-to-water distance result in a high diffusing capacity for these gills, which means that $G$. ingens requires a lower oxygen gradient to take up a given amount of oxygen. The low hemocyanin concentration is in the range predicted to be necessary on the basis of other physiological properties (Belman and Childress, 1976; Sanders and Childress, 1990a,b) and is sufficient to account for approximately $75 \%$ of the oxygen in the blood at $0.8 \mathrm{kPa}$. The hemocyanin properties are clearly appropriate for 


\section{Life at stable low oxygen levels 1227}

a hemocyanin functioning at very low partial pressures. It appears that individuals of $G$. ingens living at higher oxygen concentrations off Hawaii have a hemocyanin with a higher $P_{50}$ (Sanders and Childress, 1990b), supporting the adaptive nature of the high affinity found in California animals. Other midwater crustaceans from Hawaii also have hemocyanins with lower affinities than found off California (Sanders and Childress, 1990a).

In addition to the crustaceans, some fragmentary observations have been made for other groups, suggesting that they use similar mechanisms. For example, larger gills have been observed in OML species of fishes (Parin, 1961; Ebeling and Weed, 1963; Gibbs and Hurwitz, 1967) and cephalopods (Roper, 1969; Young, 1972). High-affinity hemoglobins have been found in midwater OML fishes (A. J. Arp and J. J. Childress, unpublished observations) and a benthic OML fish (Yang et al. 1992). A single observation suggesting lowaffinity hemoglobins in OML fishes (Douglas et al. 1976) was almost certainly an error due to the use of blood from trawlcaptured specimens without measuring or adjusting the $\mathrm{pH}$ in the whole blood used in their studies. The blood of trawlcaught midwater fishes is typically very acidotic $(\mathrm{pH}$ values of 6-6.5 being common, A. J. Arp and J. J. Childress, unpublished observations). The same species of Vinciguerria lucetia measured under more physiological conditions gave $P_{50}$ values below $1.3 \mathrm{kPa}$ and had large Bohr and Root effects, explaining the results of Douglas et al. (1976) (A. J. Arp and J. J. Childress, unpublished observations).

Thus, it appears that the crustaceans, fishes and cephalopods all follow similar modes of adaptation to the OMLs; that is, the development of abilities to regulate their oxygen consumption rates very effectively so that they can remain primarily dependent upon aerobic metabolism down to $P_{\mathrm{O}_{2}}$ values of $0.5-0.8 \mathrm{kPa}$. This regulation is made possible by adaptations at the tissue and organ levels which increase the supply of medium to the respiratory surfaces, increase the diffusing capacity of the respiratory surfaces and manipulate the internal $P_{\mathrm{O}_{2}}$ to maintain suitable gradients for diffusion of oxygen at the gills and tissues. There are almost certainly also adaptations at the level of the oxygen-consuming tissues to allow aerobic functioning at these very low blood $P_{\mathrm{O}_{2}}$ values, but these have not been studied. One possibility is that the high lipid contents (greater than $10 \%$ of wet body mass in some cases) found in some midwater OML fishes and crustaceans (Childress and Nygaard, 1973, 1974; Neighbors and Nafpaktitis, 1982) could result in more rapid rates of diffusion of oxygen through tissues to the mitochondria (Desaulniers et al. 1996). However, since such high lipid contents are also found in animals from comparable depths without pronounced oxygen minima (Donnelly et al. 1990, 1994; Torres et al. 1994a,b), it is unlikely that this is a specific adaptation to the oxygen minimum layer.

We would expect that polychaetes would have a pattern of adaptations similar to those of fishes, cephalopods and crustaceans, but other major groups lack the organ and tissue specializations to adapt to the OMLs in this manner. The study of these groups is made especially difficult by the fact that they are often fragile organisms with low metabolic rates. In preliminary studies, we have found excellent regulation in midwater ctenophores, chaetognaths and the aberrant polychaete Poeobius meseres (J. J. Childress and E. V. Thuesen, unpublished observations). In the case of the ctenophores, this regulation may be possible because the major oxygen demand is peripheral to the body in the ctene rows, resulting in short diffusion distances to the mitochondria. For the chaetognaths, the animals are so thin that diffusion distances are always relatively modest. In Poeobius meseres, the organ and tissue specializations, including the properties of their circulating chlorocruorin, may be critical (Robbins, 1965). For the remaining groups, such as nemerteans and cnidarians, no data are available. Although one can conceive of specializations to reduce diffusion distances by peripheral location of mitochondria, it is difficult to envision how such large organisms could be fully aerobic at low oxygen partial pressures.

It is clear that a variety of midwater fishes, crustaceans and cephalopods from the seas off California can regulate their routine oxygen consumption rates down to $0.8 \mathrm{kPa}$, with others going as low as $0.4 \mathrm{kPa}$, and most OML species can continue to consume $\mathrm{O}_{2}$ all the way to anoxia (Childress, 1969, 1971 $a, b$, 1975; Torres et al. 1979). The very limited anaerobic capacity of many of these species $(<0.5 \mathrm{~h}$ anoxic) suggests that these regulated rates represent the bulk of the metabolic demands (Childress, 1969, 1971a,b, 1975; Torres et al. 1979). There is, however, no evidence that midwater animals are able to regulate their routine oxygen consumption rates down to the level of $0.3 \mathrm{kPa}$ or less found in large areas of the most highly developed OMLs. Thus, we suggest that the notable reduction in biomass found in OMLs with oxygen contents below approximately $0.15 \mathrm{ml}^{-1}$ is due to an inability of midwater species to adapt to regulating their $\mathrm{O}_{2}$ consumption rates below this level, forcing them to rely on anaerobic metabolism for extended periods for survival in these OMLs.

Another important aspect of the regulation of $\mathrm{O}_{2}$ uptake by these species is that the oxygen consumption rates of midwater fishes, crustaceans and cephalopods which are resident at OML depths are typically almost an order of magnitude lower than the rates of comparable animals which live at the surface or migrate to the surface (Childress, 1995). The rates of fishes, in fact, approach those of benthic species (Childress et al. 1990), while those of some cephalopods are lower than those of benthic species and approach those of cnidarians (Thuesen and Childress, 1994; Seibel et al. 1997). Without such low rates, these species could not regulate down to the low $\mathrm{O}_{2}$ levels of the OMLs off California. An example of the importance of this can be found in the diurnally vertically migratory oplophorid decapod crustaceans of the genera Oplophorus, Acanthephyra and Systellaspis. These vertically migrating species have much higher metabolic rates than do their congeners and confamilials which live at comparable daytime OML depths (Donnelly and Torres, 1988) and are found throughout the temperate and tropical oceans of the world except where OMLs are well- 
developed (Omori, 1974). Thus, the lower metabolic rates of midwater fishes, crustaceans and cephalopods are clearly adaptive in a functional sense for survival in the OMLs, but whether they are adaptations to the OMLs in an evolutionary sense is another story, as we shall see below.

\section{Increased reliance on anaerobic metabolism as an adaptation to the oxygen minimum layer}

Given the substantial abilities of midwater animals to extract $\mathrm{O}_{2}$ from water and the much greater energy yield of aerobic metabolism, we would expect anaerobic metabolism to be used at most as a supplement to aerobic metabolism and not as the sole form of oxidative metabolism. In this context, we will distinguish between the use of anaerobic metabolism to support activity levels and metabolic rates above routine rates and its use to support part of the routine rates.

Several cases where midwater crustaceans must rely on anaerobic metabolism to satisfy part of their routine metabolic needs have been documented. The large copepod Gaussia princeps has a $P_{\mathrm{c}}$ of approximately $1.6 \mathrm{kPa}$ but lives part of the time at $P_{\mathrm{O}_{2}}$ values as low as $0.8 \mathrm{kPa}$ off California. It has a substantial anaerobic capacity, being able to survive anoxia for between 10 and $14 \mathrm{~h}$. It has been proposed that when it is in the core of the OML as much as $50 \%$ of its metabolic requirements may need to be provided by anaerobic metabolism, but as it moves up or down from the lowest $\mathrm{O}_{2}$ concentrations this percentage drops rapidly (Childress, 1977). The large isopod Anuropus bathypelagicus is parasitic on the very large medusa Deepstaria enigmata (Barham and Pickwell, 1969). Anuropus bathypelagicus can only regulate its $\mathrm{O}_{2}$ consumption down to $1.9 \mathrm{kPa}$, although it lives down to at least $1.3 \mathrm{kPa}$, but it has a substantial capacity for anaerobic survival (Childress, 1975). Another cnidarian parasite, Hyperia sp., can survive without $\mathrm{O}_{2}$ for $30 \mathrm{~h}$ (Childress, 1975). It has been suggested that these parasitic species can more readily use anaerobic metabolism because of the abundant substrate supply represented by their hosts. The benthopelagic galatheid Pleuroncodes planipes is able to regulate its $\mathrm{O}_{2}$ consumption rate down to $0.26 \mathrm{kPa}$ when resting on the bottom; however, in the eastern tropical Pacific where this species lives, $\mathrm{O}_{2}$ concentration is often at or below this level at depths where the crabs are found (Boyd, 1967; Quetin and Childress, 1976). The substantial anaerobic capacity of this species, greater than $12 \mathrm{~h}$ of anoxia, is probably necessary for its forays into low- $\mathrm{O}_{2}$ water (Childress, 1975). Thus, it is apparent that part of the routine metabolic energy needs of some midwater crustaceans when in OMLs may be supplied by anaerobic metabolism, although the majority of species do not appear to rely on this mechanism. Our general impression is that vertically migrating midwater cephalopods may have greater anaerobic capacities than comparable crustaceans and may rely more on anaerobic metabolism for part of their routine metabolism in the OMLs, but this point has not been well documented.

In the very highly developed OMLs, where $\mathrm{O}_{2}$ content is less than approximately $0.15 \mathrm{mll}^{-1}$, most species migrate out on a daily basis (Vinogradov and Voronina, 1962; Childress, 1968; Brinton, 1979; Sameoto et al. 1987; Kinzer et al. 1993; Saltzman and Wishner, 1997a,b). Given the observed limitations on aerobic adaptations, we propose that these species rely to a great extent on anaerobic metabolism while at depth and then burn off their oxygen debts when they migrate to higher oxygen concentrations at night. As shown by Teal and Carey (1967), however, these species still have the ability to obtain some $\mathrm{O}_{2}$ from the water even at these very low concentrations. Thus, the limitation of biomass below $0.15 \mathrm{ml} \mathrm{O}_{2} \mathrm{l}^{-1}$ may be the result of relatively few species being able to live largely anaerobically for half of each day and then undertake an extensive migration to shallower depths.

The support of activity levels above routine almost certainly requires anaerobic metabolism for most fishes, crustaceans and cephalopods which live at $P_{\mathrm{O}_{2}}$ values as low as $0.8 \mathrm{kPa}$ or so, since the data generally show that these animals are only able to regulate their routine rates to the lowest $P_{\mathrm{O}_{2}}$ that they encounter (Childress, 1968, 1971a,b; Torres et al. 1979; Cowles and Childress, 1988; Seibel et al. 1997). Higher activity levels must require anaerobic metabolism for most of their support. This should have the effect of restricting higher levels of activity depending upon the anaerobic capacity of any given species.

Analyses of enzyme activities have also been used as an approach to looking for greater reliance on anaerobic metabolism in OML species. In a series of midwater fishes, there was no evidence of enhanced glycolytic capacity in those species living at $0.25 \mathrm{mlO}_{2} \mathrm{l}^{-1}$ compared with those living shallower and deeper (Childress and Somero, 1979). In a series of flatfishes living off the California coast, there was also no apparent increase in glycolytic capacity (pyruvate kinase and lactate dehydrogenase) relative to aerobic capacity (citrate synthase and malate dehydrogenase) (Vetter et al. 1994). In a comparison of a shallow-living benthic scorpaenid species, Scorpaena guttata, with an OML-inhabiting species, Sebastolobus alascanus, there was little indication of a greater glycolytic poise in brain or white muscle of the OML species (Yang and Somero, 1993). However, in the OML species, the red muscle lactate dehydrogenase (LDH) activities were greater than the white muscle activities, a very unusual finding suggesting that this species may use glycolysis for a greater fraction of its routine metabolic needs than is usually the case. In addition, the heart of $S$. alascanus has only a single LDH, which appears to be an anaerobically poised one unlike the usual finding of aerobically poised LDH in heart tissues (Yang et al. 1992). This finding suggests that the heart may use anaerobic metabolism to a greater extent than is usual for fishes.

The sum of these lines of evidence is that, in OMLs with $\mathrm{O}_{2}$ contents above $0.20 \mathrm{mll}^{-1}$, most of the more complex animals rely on aerobic metabolism for their routine rates of metabolism but quickly begin to use anaerobic metabolism at higher activity levels. This shift to anaerobic metabolism is expected to happen at much lower relative activity levels than is typical of more oxic environments. 


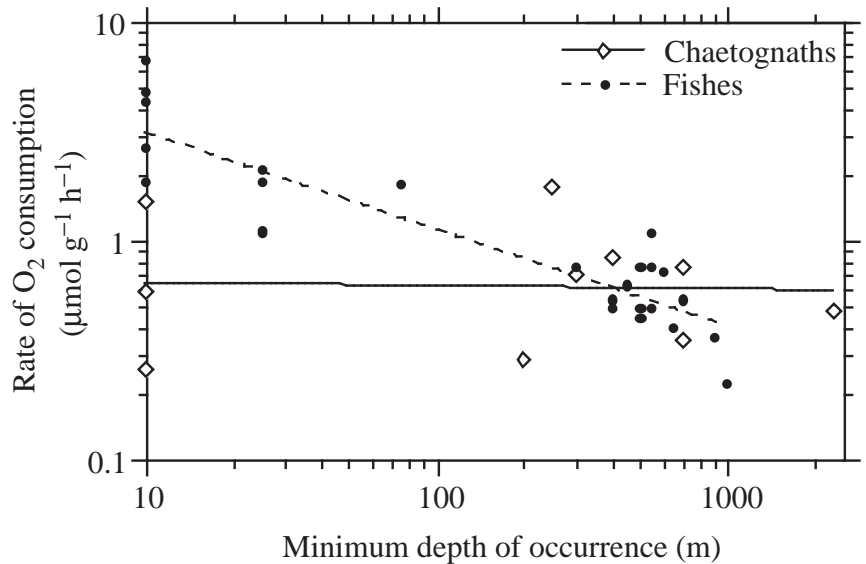

Fig. 4. Routine rates of oxygen consumption, measured at $5^{\circ} \mathrm{C}$, of midwater fishes and chaetognaths from the seas off California (Torres et al. 1979; Thuesen and Childress, 1993).

\section{Reduced metabolic rates as an adaptation to the oxygen minimum layer}

The metabolic rates of deeper-living pelagic fishes, crustaceans and cephalopods are much lower than those of surface-living species even when temperature is taken into account (Fig. 4) (Childress, 1971a,b, 1975, 1995; Torres et al. 1979; Childress et al. 1990). Since this phenomenon has recently been reviewed in depth, we will only concern ourselves here with the relationship between these reduced rates and the OMLs (Childress, 1995). Although, as noted earlier, these lower metabolic rates in pelagic OML fishes, crustaceans and cephalopods are functionally adaptive for their aerobic survival in the OMLs, they do not appear to have evolved as adaptations to the low oxygen levels in the OMLs. This statement is based on several lines of evidence.

(1) Midwater crustaceans and fishes living at OML depths $(400-800 \mathrm{~m})$ in regions with higher oxygen concentrations have metabolic rates comparable with those of the same or similar species living at oxygen concentrations as low as $0.20 \mathrm{ml}^{-1}$, while having much poorer regulatory abilities (Figs 3, 5) (Donnelly and Torres, 1988; Torres and Somero, 1988a,b; Cowles et al. 1991; Torres et al. 1994a,b; Seibel et al. 1997).

(2) Midwater crustaceans, fishes and cephalopods living below the oxygen minimum layer have lower metabolic rates and higher $P_{\mathrm{c}}$ values than those living in the minimum layer (Childress, 1975; Cowles et al. 1991; Seibel et al. 1997).

(3) Non-visual deep-sea groups, such as cnidarians and chaetognaths, do not show any decrease in metabolic rate with depth off the California coast, a region with a minimum $\mathrm{O}_{2}$ content of approximately $0.20 \mathrm{mll}^{-1}$ (Fig. 4) (Thuesen and Childress, 1993, 1994).

Thus, in those pelagic groups that do show reduced metabolic rates at OML depths, the rates are reduced whether $\mathrm{O}_{2}$ content is low or not, which refutes the suggestion that the lower metabolic rates are an adaptation to the OMLs.

In a group of benthic crustaceans from the seas off California, there is a small decline in metabolic rate with depth

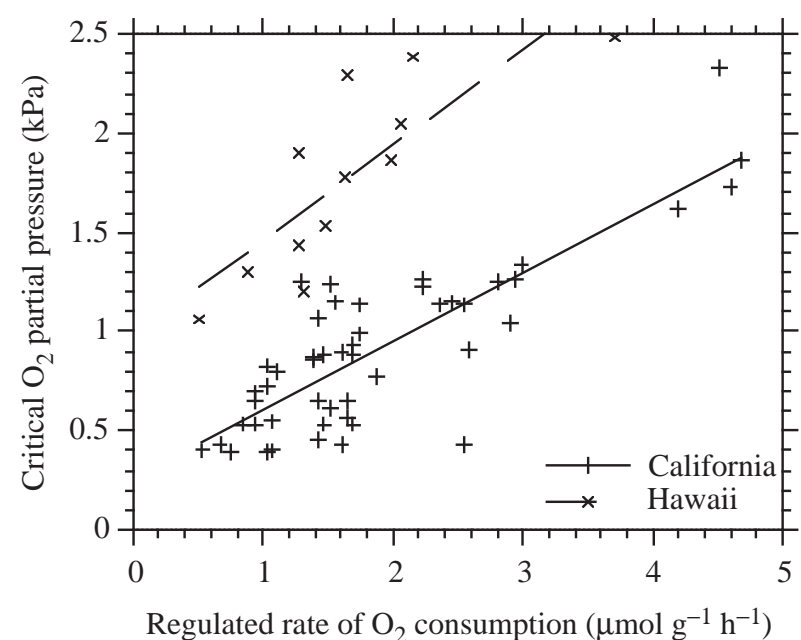

Fig. 5. The relationship between critical $\mathrm{O}_{2}$ partial pressure $\left(P_{\mathrm{c}}\right)$ and regulated rates of $\mathrm{O}_{2}$ consumption for individuals of the lophogastrid mysid Gnathophausia ingens from the seas off California (+) (minimum $P_{\mathrm{O}_{2}}$ approximately $0.8 \mathrm{kPa}$ ) and from the seas off the Hawaiian Islands $(\times)$ (minimum $P_{\mathrm{O}_{2}}$ approximately $2.7 \mathrm{kPa}$ ) (Childress, 1971a,b; Cowles et al. 1991). The slopes of the regression lines are not significantly different, but the lines are different in elevation (ANCOVA, $P<0.0001$ ). The metabolic rates of the two groups are not significantly different at $P_{\mathrm{O}_{2}}$ values above the $P_{\mathrm{c}}$ values (Childress, 1971a; Cowles et al. 1991).

for the caridian and peneid decapods, but not for the other groups (Childress et al. 1990). However, there was no sign of a relationship between metabolic rate and the OML because deeper-living species had comparable or lower metabolic rates. The suggestion has been made that the low metabolic rates (measured or inferred from enzyme activities) of two OMLdwelling benthic species, the Dover sole and Sebastolobus alascanus, are partially adaptations to the OML (Yang and Somero, 1993; Vetter et al. 1994). In the case of the Dover sole, this contention rests upon the description of the results of unpublished experiments showing lower metabolic rates and feeding rates in fish acclimated to hypoxia (Vetter et al. 1994). In the case of $S$. alascanus, this contention rests on the comparison with a shallower-living scorpaenid species (Yang and Somero, 1993). However, it has been found that a deeperliving congener, S. altivelis, has lower levels of glycolytic and Krebs cycle enzymes and therefore presumably a lower metabolic rate while living at higher $P_{\mathrm{O}_{2}}$ values (Siebenaller and Somero, 1982). It may be, as these authors suggest, that benthic fishes are different from pelagic ones and that their reduced metabolic rates are adaptations to the OML, but the definitive test of measuring the metabolic rates of the same or similar species living in regions with higher minimum $\mathrm{O}_{2}$ content has yet to be carried out.

A case where it is likely that the metabolic rates are reduced in OML inhabitants is where resting stages are in the minimum layer. High concentrations of apparently overwintering stage $\mathrm{V}$ Calanus helgolandicus copepods have been found in the OML off California and Baja California (Longhurst, 1967; 
Alldredge et al. 1984). It has also been suggested, on the basis of observations from submersibles, that some species of diurnally vertically migrating fishes have reduced levels of activity, 'lethargy' and presumably lower metabolic rates at their daytime depths in the OML (Barham, 1971). Such reduced rates could also play a role in allowing aerobic adaptation to the OMLs without reducing the overall metabolic potential of vertically migrating species. The species for which this is suggested are close to neutrally buoyant and so little metabolic energy would need to go into maintaining their vertical position in the water column. Whether this is an adaptation to the OML or simply an energy conservation mechanism of vertical migrators, it would be expected to be adaptive for aerobic life in the OMLs.

In summary, there are many data indicating that lower metabolic rates in OML species are adaptive, but not adaptations, to the OMLs. There are some other situations where OML animals may have further reduced metabolic rates, but it has not been resolved whether these are evolved adaptations to OML conditions or adaptations to the deep-sea at OML depths which are also adaptive for life in the OML. Anaerobic metabolism appears to be essential to support activity levels above routine levels for many OML species and to support a large part of the metabolic needs of diurnal vertical migrators from regions with $\mathrm{O}_{2}$ concentrations below $0.20 \mathrm{mll}^{-1}$ during their daytime residence in the OML. However, the primary adaptation for life in OMLs with more than $0.20 \mathrm{ml} \mathrm{O}_{2} \mathrm{l}^{-1}$, as well as an important one for even lower concentrations, is the ability to regulate rates of oxygen consumption to very low $\mathrm{O}_{2}$ partial pressures.

Funding for this work over the years was primarily derived from NSF grants to J.J.C., most recently OCE 9415543. We thank all the ships' crews, staff personnel and colleagues who have made our work possible over the years.

\section{References}

Alldredge, A. L., Robison, B. H., Fleminger, A., Torres, J. J., King, J. M. AND Hamner, W. M. (1984). Direct sampling and in situ observation of a persistent copepod aggregation in the mesopelagic zone of the Santa Barbara Basin. Mar. Biol. 80, 75-81.

Banse, K. (1964). On the vertical distribution of zooplankton in the sea. Prog. Oceanogr. 2, 53-125.

BARHAM, E. G. (1971). Deep-sea fishes: lethargy and vertical orientation. In Proceedings of an International Symposium on Biological Sound Scattering in the Ocean (ed. G. B. Farquhar), pp. 100-118. Washington, DC: Superintendent of Documents.

Barham, E. G. AND Pickwell, G. V. (1969). The giant isopod, Anuropus: A scyphozoan symbiont. Deep-Sea Res. 16, 525-529.

Belman, B. W. AND Childress, J. J. (1976). Circulatory adaptations to the oxygen minimum layer in the bathypelagic mysid Gnathophausia ingens. Biol. Bull. mar. biol. Lab., Woods Hole 150, 15-37.

BÖTTGER-SCHNACK, R. (1996). Vertical structure of small metazoan plankton, especially non-calanoid copepods. I. Deep Arabian Sea. J. Plankton Res. 18, 1073-1101.
Boyd, C. (1967). The benthic and pelagic habitats of the red crab Pleuroncodes planipes. Pac. Sci. 21, 394-403.

BRINTON, E. (1979). Parameters relating to the distributions of planktonic organisms, especially Euphausiids in the eastern tropical Pacific. Prog. Oceanogr. 8, 125-189.

ChILDRESS, J. J. (1968). Oxygen minimum layer: vertical distribution and respiration of the mysid Gnathophausia ingens. Science 160, 1242-1243.

Childress, J. J. (1969). The respiratory physiology of the oxygen minimum layer mysid Gnathophausia ingens, p. 142. $\mathrm{PhD}$ thesis, Stanford University.

ChILdRESS, J. J. (1971a). Respiratory adaptations to the oxygen minimum layer in the bathypelagic mysid Gnathophausia ingens. Biol. Bull. mar. biol. Lab., Woods Hole 141, 109-121.

CHILDRESS, J. J. (1971b). Respiratory rate and depth of occurrence of midwater animals. Limnol. Oceanogr. 16, 104-106.

ChILdRESS, J. J. (1975). The respiratory rates of midwater crustaceans as a function of depth occurrence and relation to the oxygen minimum layer off Southern California. Comp. Biochem. Physiol. 50A, 787-799.

ChILDRESS, J. J. (1977). Effects of pressure, temperature and oxygen on the oxygen consumption rate of the midwater copepod Gaussia princeps. Mar. Biol. 39, 19-24.

ChildRESS, J. J. (1995). Are there physiological and biochemical adaptations of metabolism in deep-sea animals? Trends Ecol. Evol. 10, 30-36.

Childress, J. J., Cowles, D. L., Favuzzi, J. A. And Mickel, T. J. (1990). Metabolic rates of benthic deep-sea decapod crustaceans decline with increasing depth primarily due to the decline in temperature. Deep-Sea Res. 37, 929-949.

Childress, J. J. AND NygaARd, M. H. (1973). The chemical composition of midwater fishes as a function of depth of occurrence off Southern California. Deep-Sea Res. 20, 1093-1109.

Childress, J. J. AND NygaARd, M. H. (1974). The chemical composition and relative buoyancy of midwater crustaceans as a function of depth off Southern California. Mar. Biol. 27, 225-238.

Childress, J. J. AND Somero, G. N. (1979). Depth related enzymic activities in muscle, brain and heart of deep-living pelagic marine teleosts. Mar. Biol. 52, 273-283.

Cowles, D. L. AND ChILdRESS, J. J. (1988). Swimming speed and oxygen consumption in the bathypelagic mysid Gnathophausia ingens. Biol. Bull. mar. biol. Lab., Woods Hole 175, 111-121.

Cowles, D. L., Childress, J. J. AND Wells, M. E. (1991). Metabolic rates of midwater crustaceans as a function of depth of occurrence off the Hawaiian Islands: Food availability as a selective factor? Mar. Biol. 110, 75-83.

Desaulniers, N., Moerland, T. S. And Sidell, B. S. (1996). High lipid content enhances the rate of oxygen diffusion in fish skeletal muscle. Am. J. Physiol. 271, R42-R47.

Donnelly, J. AND TORRES, J. J. (1988). Oxygen consumption of midwater fishes and crustaceans from the eastern Gulf of Mexico. Mar. Biol. 97, 483-494.

Donnelly, J., Torres, J. J., Hopkins, T. L. And Lancraft, T. M. (1990). Proximate composition of Antarctic mesopelagic fishes. Mar. Biol. 106, 13-23.

Donnelly, J., Torres, J. J., Hopkins, T. L. And Lancraft, T. M. (1994). Chemical-composition of Antarctic zooplankton during austral fall and winter. Polar Biol. 14, 171-183.

Douglas, E. L., Friedl, W. A. And Pickwell, G. V. (1976). Fishes 


\section{Life at stable low oxygen levels 1231}

in oxygen-minimum zones: blood oxygenation characteristics. Science 191, 957-959.

Ebeling, A. H. And Weed III, W. H. (1963). Melamphaidae. III. Systematics and distribution of the species in the bathypelagic fish genus Scopelogadus Vaillant. Dana Reports 60, 1-58.

GibBS, R. H. AND HuRwitz, B. A. (1967). Systematics and zoogeography of the stomiatoid fishes, Chauliodus pammelas and C. sloani, of the Indian Ocean. Copeia 1967, 798-805.

Harvey, P. H. And Pagel, M. D. (1991). The Comparative Method in Evolutionary Biology. New York: Oxford University Press. 239pp.

Herbert, T. D. AND SARmiento, J. L. (1991). Ocean nutrient distribution and oxygenation: Limits on the formation of warm saline bottom water over the past 91 m.y. Geology 20, 15-18.

JesPerson, P. (1935). Quantitative investigations on the distribution of macroplankton in the different oceanic regions. Dana Reports 7 , 44.

JudKINS, D. L. (1980). Vertical distribution of zooplankton in relationship to the oxygen minimum off Peru. Deep-Sea Res. 27, 475-487.

KAIHO, K. (1991). Global changes of Palaeogene aerobic/anaerobic benthic foraminifera and deep-sea circulation. Palaeogeogr. Palaeoclimatol. Palaeoecol. 83, 65-83.

KAMYKowsKi, D. AND ZentaRA, S.-J. (1990). Hypoxia in the world ocean as recorded in the historical data set. Deep-Sea Res. 37, 1861-1874.

KenNetT, J. P. AND Ingram, B. L. (1995). A 20,000-year record of ocean circulation and climate change from the Santa Barbara basin. Nature 377, 510-514.

KennetT, J. P. And StotT, L. D. (1991). Abrupt deep-sea warming, palaeoceanographic changes and benthic extinctions at the end of the Palaeocene. Nature 353, 225-229.

KinZer, J., BötTGer-Schnack, R. And Schulz, K. (1993). Aspects of horizontal distribution and diet of myctophid fish in the Arabian Sea with reference to deep water oxygen deficiency. Deep-Sea Res. II 40, 783-800.

LONGHURST, A. (1967). Vertical distribution of zooplankton in relation to the eastern Pacific oxygen minimum. Deep-Sea Res. 14, 51-63.

Meek, R. P. ANd ChILdRess, J. J. (1973). Respiration and the effect of pressure in the mesopelagic fish Anoplogaster cornuta (Beryciformes). Deep-Sea Res. 20, 1111-1118.

Neighbors, M. A. And Nafpaktitis, B. G. (1982). Lipid compositions, water contents, swimbladder morphologies and buoyancies of nineteen species of midwater fishes (18 myctophids and 1 neoscopelid). Mar. Biol. 66, 207-215.

Olson, D. B., Hitchcock, G. L., Fine, R. A. And Warren, B. A. (1993). Maintenance of the low-oxygen layer in the central Arabian Sea. Deep-Sea Res. II 40, 673-685.

OMORI, M. (1974). The biology of pelagic shrimps in the ocean. $A d v$. mar. Biol. 12, 233-324.

PARIN, N. V. (1961). The distribution of deep-sea fishes in the upper bathypelagic layer of the subarctic waters of the northern Pacific Ocean. Akad. Nauk S.S.R. 45, 259-278.

PICKFORD, G. E. (1946). Vampyroteuthis infernalis Chun, an archaid dibranchiate cephalopod: natural history and distribution. 29, 1-40.

QueTIN, L. B. AND ChILDREss, J. J. (1976). Respiratory adaptations of Pleuroncodes planipes Stimpson to its environment off Baja, California. Mar. Biol. 38, 327-334.

RobBins, D. E. (1965). The biology and morphology of the pelagic annelid Poeobius meseres Heath. J. Zool. 146, 197-212.
ROPER, C. F. (1969). Systematics and zoogeography of the worldwide bathypelagic squid Bathyteuthis (Cephalopoda: Oegopsida). U.S. natn. Mus. Bull. 291, 1-210.

SALtZMAN, J. AND Wishner, K. (1997a). Zooplankton ecology in the eastern tropical Pacific oxygen minimum zone above a seamount. I. General trends. Deep-Sea Res. 44, 907-930.

SALtZMAn, J. AND Wishner, K. (1997b). Zooplankton ecology in the eastern tropical Pacific oxygen minimum zone above a seamount. II. Vertical distribution of copepods. Deep-Sea Res. 44, 931-954.

Sameoto, D. D., Guglielmo, L. AND Lewis, M. K. (1987). Day/night vertical distribution of euphausiids in the eastern tropical Pacific. Mar. Biol. 96, 235-245.

SANDERs, N. K. AND ChILDRESS, J. J. (1990a). A comparison of the respiratory function of the hemocyanins of vertically migrating and non-migrating oplophorid shrimps. J. exp. Biol 152, 167-187.

SANDERs, N. K. AND ChILdRESS, J. J. (1990b). Adaptations to the deep-sea oxygen minimum layer: Oxygen binding by the hemocyanin of the bathypelagic mysid, Gnathophausia ingens Dohrn. Biol. Bull. mar. biol. Lab., Woods Hole 178, 286-294.

SCHMIDT, J. (1925). On the contents of oxygen in the ocean on both sides of Panama. Science 61, 592-593.

Seibel, B. A., Thuesen, E. V., Childress, J. J. And Gorodezky, L. A. (1997). Decline in pelagic cephalopod metabolism with habitat depth reflects differences in locomotory efficiency. Biol. Bull. mar. biol. Lab., Woods Hole 192, 262-278.

SEWELl, R. B. S. AND FAGE, L. (1948). Minimum oxygen layer in the ocean. Nature 162, 949-951.

Siebenaller, J. F. AND SOMERo, G. N. (1982). The maintenance of different enzyme activity levels in congeneric fishes living at different depths. Physiol. Zool. 55, 171-179.

Teal, J. M. and Carey, F. G. (1967). Respiration of a euphausiid from the oxygen minimum layer. Limnol. Oceanogr. 12, 548-550.

Thuesen, E. V. And Childress, J. J. (1993). Enzymatic activities and metabolic rates of pelagic chaetognaths: Lack of depth-related declines. Limnol. Oceanogr. 38, 935-948.

Thuesen, E. V. AND ChILdRess, J. J. (1994). Oxygen consumption rates and metabolic enzyme activities of oceanic California medusae in relation to body size and habitat depth. Biol. Bull. mar. biol. Lab., Woods Hole 187, 84-98.

Torres, J. J., Aarset, A. V., Donnelly, J., Hopkins, T. L., LANCRAFT, T. M. AND AINLEY, D. (1994a). Metabolism of Antarctic micronektonic Crustacea as a function of depth of occurrence and season. Mar. Ecol. Prog. Ser. 113, 207-219.

Torres, J. J., Belman, B. W. ANd Childress, J. J. (1979). Oxygen consumption rates of midwater fishes as a function of depth of occurrence. Deep-Sea Res. 26A, 185-197.

Torres, J. J., Donnelly, J., Hopkins, T. L., Lancraft, T. M., Aarset, A. V. AND Ainley, D. G. (1994b). Proximate composition and overwintering strategies of Antarctic micronektonic Crustacea. Mar. Ecol. Prog. Ser. 113, 221-232.

Torres, J. J. AND Somero, G. N. (1988a). Metabolism, enzymic activities and cold adaptation in Antarctic mesopelagic fishes. Mar. Biol. 98, 169-180.

Torres, J. J. AND Somero, G. N. (1988b). Vertical distribution and metabolism in Antarctic mesopelagic fishes. Comp. Biochem. Physiol. 90B, 521-528.

Tyson, R. V. And Pearson, R. H. (1991). In Modern and Ancient Continental Shelf Anoxia (ed. R. V. Tyson and R. H. Pearson), pp. 1-24. London: The Geological Society.

Vetter, R. D., Lynn, E. A., Garza, M. And Costa, A. S. (1994). Depth zonation and metabolic adaptation in Dover sole, 


\section{J. J. Childress And B. A. Seibel}

Microstomus pacificus and other deep-living flatfishes: factors that affect the sole. Mar. Biol. 120, 145-159.

Vinogradov, M. E. AND Voronina, N. M. (1962). Influence of the oxygen deficit on the distribution of plankton in the Arabian Sea. Deep-Sea Res. 9, 523-530.

Wishner, K., Levin, L., Gowing, M. And Mullineaux, L. (1990). Involvement of the oxygen minimum in benthic zonation on a deep seamount. Nature 346, 57-59.

WyrtKI, K. (1962). The oxygen minima in relation to ocean circulation. Deep-Sea Res. 9, 11-23.

WyrtKi, K. (1967). Circulation and water masses in the eastern equatorial Pacific Ocean. Int. J. Oceanol. Limnol. 1, 117-147.

YAnG, T.-H., LaI, N. C., Graham, J. B. AND Somero, G. N. (1992).
Respiratory, blood and heart enzymatic adaptations of Sebastolobus alascanus (Scorpaenidae; Teleostei) to the oxygen minimum zone: a comparative study. Biol. Bull. mar. biol. Lab., Woods Hole 183, 490-499.

YANG, T.-H. AND Somero, G. N. (1993). Effects of feeding and food deprivation on oxygen consumption, muscle protein concentration and activities of energy metabolism in muscle and brain of shallowing-living (Scorpaena guttata) and deep-living (Sebastalobus alascanus) scorpaenid fishes. J. exp. Biol. 181, 213-232.

YounG, R. E. (1972). The systematics and areal distribution of pelagic cephalopods from the seas off southern California. Smith. Contrib. Zool. 97, 1-159. 